Article Review

\title{
Pola Distribusi dan Kelimpahan Bulu Babi (Echinoidea) yang Ada di Perairan
}

\author{
Rivani Usman* \\ * Jurusan Manajemen Sumber Daya Perairan, Fakultas Perikanan dan IImu Kelautan, Universitas Negeri \\ Gorontalo. Email: vanirivanivani@gmail.com
}

\section{Introduction}

Indonesia sebagai negara kepulauan, telah dikenal memiliki sumber daya alam yang sangat tinggi, kehidupan tumbuhan dan fauna. Ekosistem pesisir dan laut memberikan sumber herbal yang sangat produktif sebagai persediaan kehidupan, sumber makanan, tambang mineral, area untuk refresing dan pariwisata (Bengen, 2000 dalam Yudasmara, 2013; Nane, 2019a; 2019c). Satu fase ekosistem ini dan memiliki peran penting bagi kehidupan laut adalah bulu babi. Bulu babi berlabel fauna invertebrata dapat ditemukan di hampir semua perairan pesisir, mulai dari daerah pasang surut hingga perairan dalam. Bulu babi memutuskan perairan yang jernih dan airnya tampak tenang. Secara umum, masing-masing spesies memiliki habitat tertentu, seperti sektor rata-rata terumbu karang, daerah peningkatan ganggang, hamparan rumput laut, koloni karang tetap dan karang mati (RadJab, 2004 dalam Yudasmara, 2013).

Pantai adalah daerah sekitar yang menjadi batas antara laut dan darat. Pantai ini memiliki beragam kehidupan laut, salah satunya yaitu bulu babi. Bulu babi tercakup dalam klasifikasi Echinodermata dan Echinodermata yang merupakan hewan laut yang memiliki struktur bundar dan memiliki duri pada kulitnya yang dapat dipindahkan. (Ratna, 2002 dalam Noviana dkk 2019). Bulu babi adalah hewan herbivora, karena rejimen makanan landak laut biasanya memakan alga yang terletak di terumbu karang. Bulu babi memiliki pertahanan tubuh (duri) yang membuat organisme ini sesuai untuk bertahan hidup dan mempertahankan diri dari organisme laut. Bulu babi di beberapa lokasi memiliki edisi dalam bentuk morfologis, variasi dalam kerang, duri dan gonad sangat dipengaruhi oleh lingkungan di belakang perairan vegetasi, ketersediaan makanan, topografi air, salinitas, pH, dan kedalaman (Oemarjati dan Wardhana, 1990 dalam Noviana dkk 2019).

Di Indonesia, ada sekitar delapan puluh empat jenis bulu babi dari 31 famili dan empat puluh delapan genera (Clark dan Rowe, 1971 dalam Purnomo dkk, 2019). Bulu babi dibuka dari tempat pasang surut dangkal ke laut dalam (Jeng, 1998 dalam Purnomo dkk, 2019). Bulu babi biasanya mendiami ekosistem terumbu karang dan lapisan rumput laut dan memilih substrat yang 
sulit, khususnya substrat di lapisan rumput laut yang merupakan campuran dari pasir dan fragmen karang (Aziz, 1993 dalam Purnomo dkk, 2019; Nane et al., 2020).

Echinodermata berasal dari kata Yunani 'echinos', yang artinya 'duri dan derma', yang artinya kulit dan lebih tinggi dianggap sebagai hewan berkulit duri (Jasin, 1984 dalam Erlangga dkk, 2018). Echinodermata dibagi menjadi lima kelas, yaitu Asteroid ea (Bintang Laut), Crinoline (Sea Lily), kelas Echinoderm (Bulu Babi), kategori Hypothyroid (Teripang) dan kelas Spheroidal (Bintang Angular). Echinodermata memiliki kapasitas untuk otonomi dan regenerasi di bagian yang terputus, rusak atau hilang (Katina, 2011).

Echinodermata secara teratur diamati di perairan pantai. Di Indonesia ada banyak jenis echinodermata luar biasa dari pelatihan 5 (Nonjti, 2005 dalam Ali dkk, 2017). Echinodermata dapat hidup di berbagai habitat seperti zona rata terumbu, area ledakan ganggang, hamparan rumput laut, koloni karang hidup, dan ekosistem terumbu karang, yang merupakan habitat sejumlah jenis kehidupan laut. Salah satunya adalah dari kru Echinoderm yang cukup terkenal (Clark, 1976; Birkeland, 1989) dalam ( Yusron, 2010).

Echinodermata merupakan invertebrata laut yang dicirikan melalui kulit yang keras dan berduri. Echinodermata memiliki aktivitas yang akrab di setiap kedalaman lautan, dari daerah pasang surut hingga zona abyssal. Filum mengandung bulat 7000 spesies yang berada dan 13.000 spesies fosil yang dilambangkan melalui bintang laut yang dianggap luas, yang merupakan citra reguler dari laut herbal (Pawson,2007 dalam Ahmed dan Farooq, 2016). Ini adalah filum terbesar tanpa jenis terestrial atau air tawar (Brusca 2003 dalam Ahmad dan Farooq, 2016), selain untuk beberapa spesies yang menghuni perairan payau, yang semuanya merupakan organisme bentik yang ada di laut.

Kelangsungan hidup Echinodermata dipengaruhi melalui unsur-unsur kimiawi air seperti suhu, salinitas, $\mathrm{pH}$, oksigen terlarut, dan lainnya. Semua echinodermata yang tinggal di laut mulai dari tempat pesisir ke kedalaman 6.000 meter. Echinodermata adalah hewan yang sangat penting dalam ekosistem laut karena fakta bahwa mereka berguna sebagai faktor dalam rantai makanan, pemakan sampah organik dan hewan kecil lainnya. Echinodermata bisa menjadi pemakan pesta atau detritus, sehingga mereka berperan dalam ekosistem laut untuk mendesain ulang sisa-sisa bahan organik yang sekarang tidak digunakan spesies (Dahuri, 2003 dalam Erlangga dkk, 2018).

Echinodermata adalah hewan yang tidak lagi bertulang belakang dan memiliki duri di permukaan kulitnya. Echinodermata dapat ditemukan di hampir semua ekosistem laut. Namun, ekosistem termudah diamati di zona pasang surut. Ini karena di setiap daerah. Pantai-pantai pasang surut berbatu yang tersusun dari bahan-bahan keras adalah area yang paling padat penduduknya dan memiliki keragaman terbesar untuk setiap spesies hewan dan tumbuhan. Diakui bahwa 
lingkungan hewan Echinodermata di alam liar memiliki dimensi populasi yang tidak lagi sama karena fakta di lingkungan tersebut terdapat interaksi spesies yang berlebihan (Katili dan Abubakar Sidik, 2011).

Menurut Zulkifli dkk (2009) dalam Arthaz (2015), kandungan materi yang berlebihan dari jumlah organik dalam suatu perairan akan berdampak pada kelimpahan organisme, di mana terdapat organisme positif yang tidak tahan atau tahan terhadap tingginya kandungan bahan organik, sehingga dominan dengan cara pasti spesies dapat terjadi. Hal ini dapat terjadi pada bulu babi, karena bulu babi adalah biota laut pemakan detritus sehingga jika jumlah bahan alami hitungan kandungan air tinggi makan, maka dominasi spesies bulu babi akan terjadi.

Kelimpahan adalah banyaknya individu dari suatu spesies dalam meter kuadrat. Kelimpahan vegetasi dipengaruhi oleh frekuensi, kepadatan, dan dominasi spesies. Frekuensi jenis menunjukkan pembukaan spesies di suatu daerah. Jenis yang terbuka secara merata akan memiliki nilai frekuensi raksasa. Kepadatan jenis menunjukkan biaya yang menggambarkan berapa banyak yang mengerikan atau berapa jenis per satuan luas. Semakin tinggi nilai kepadatan spesiesnya, semakin besar kisaran orang yang ada di unit area. Dominasi suatu jenis adalah harga yang menggambarkan penguasaan jenis-jenis tertentu dari jenis yang berbeda di masyarakat. Semakin besar harga dominasi jenis, semakin besar dampak penguasaan jenis yang berbeda (Krebs, 2000) dalam (Ariyanto, 2016).

Menurut Nystrom dkk (2000) dalam Setyawan dan Purnomo (2014), bulu babi merupakan salah satu kunci spesies (spesies keystone) untuk komunitas terumbu karang. Ini karena bulu babi adalah salah satu pengontrol populasi alga mikro. Tutupan yang berlebihan dari vegetasi rumput laut di perairan memungkinkan dengan adanya berbagai bio ta terkait dengan ekosistem rumput laut yang meliputi bulu babi untuk mencari makan, berteduh, pemijahan dan tempat berlindung yang aman untuk menghindari predator (Supono dan Arbi, 2010 dalam Setyawan dan Purnomo2014).

Bulu babi ialah hewan laut yang sering ditemukan di ekosistem air laut dengan hamparan padang lamun. Hewan-hewan ini membuat hubungan simbiosis khusus dengan ikan yang menggunakan ekosistem serta membantu ekosistem padang lamun (Romimohtarto dan Juwana,2005 dalam Waters, 2010). Selain fungsi ekologis, ternyata gonad babi memiliki makanan yang bergizi. Gonad bulu babi di pasar yang dikenal sebagai uni atau roe (Pearce dkk, 2004 dalam Waters, 2010 ), adalah bahan-bahan terkenal dan salah satu komoditas penting di beberapa lokasi internasional seperti Amerika Serikat, Kanada, Chili, Rusia, Prancis, Barbados dan Jepang yang merupakan pembeli terbesar roe bulu babi (Daggett dkk, 2005 dan Hammer dkk, 2006 dalam Waters, 2010). Pengeluaran Gonad di pasar dunia bervariasi dari US \$ 6 hingga \$ 200 per kilogram 
(Robinson, 2002 dalam Waters, 2010). Jenis-jenis yang dominan yang dapat digunakan sebagai makanan adalah Deadhead Seton, Econometric Maratha, titeating Trusteeship, Echinoderm Sp, dan Salacious Sp. (Setiabudi dan Murnyati, 1998: Darsono, 1982 dalam Waters, 2010). Permintaan komoditas ini telah meningkat dari 12 bulan ke tahun, sementara produksi gonad bulu babi telah menurun dan penangkapan berlebih di berbagai lokasi internasional (Hammer dkk, 2006 dalam Waters, 2010).

Peran bulu babi dari hasil penelitian tentang kemampuan untuk mengambil makanan bulu babi siang hari sementara pada waktu malam hari landak laut kurang energik dalam merumput, kenyataan yang relatif bertentangan dengan kebiasaan landak laut di konvensional yang menyamar hanya pada tahap tertentu dalam sehari (Gullie dkk, 1986 dalam Moningkey, 2011). Echinodermata peranannya cukup besar pada ekosistem terumbu karang, khususnya pada jaringan makanan. Bulu babi adalah herbivora, karena umumunya pola bulu babi yaitu alga yang berada di terumbu karang (Birkeland, 1997 dalam Somma dan Yuda 2018). Organ bulu babi yang berbiaya ekonomis sehingga dapat digunakan sebagai bahan makanan, khususnya gonad. Manusia lokal memahaminya lebih baik sebagai telur landak laut. Sebagai organ reproduksi, gonad adalah fasilitas pembuatan benih yang dipastikan memiliki cadangan protein tinggi (Rachmawaty, 2004 dalam Irianto, 2016). J 19

Bulu babi memiliki biaya industri karena telur mereka adalah barang dagangan perikanan yang dapat dikonsumsi bersih dan diproses sebagai makanan bergizi. Di Maluku tidak lagi dipasarkan secara komersial (Andamari dkk, 1996 dalam Syam dan Andamari, 2017).Bulu babi (Echinoderm) adalah salah satu sumber air yang praktis untuk dikembangkan sebagai penambah kisaran protein hewani (Rachmawaty, 2004 dalam Irianto, 2016). Oleh manusia yang berdiam di wilayah pesisir Indonesia Timur yang lebih dikenal sebagai 'duri babi' yang merupakan salah satu dari banyak jenis makrobiotik dari kategori Echinoderm yang dapat mencapai diameter $163 \mathrm{~mm}$ dan mencapai berat 200 gram (Radjab, 2001 dalam Irianto, 2016).

Salah satu yang ada di dasar rumput laut adalah Bulu Babi (Echinoderm). Bulu babi sebagai salah satu penghuni hamparan rumput laut, sering diamati di daerah campuran rumput laut. Keadaan ini terutama disebabkan oleh bulu babi tergantung pada sejumlah jenis rumput laut, seperti rumput laut dari, Syringe, Rhododendron, dan klan Commodore. Selain itu bulu babi juga menyukai substrat yang agak keras, dimana substrat rumput laut merupakan kombinasi yang terdiri dari campuran pasir dan fragmen karang (Aziz, 1994 dalam Suistiawan dan Rahman, 2019). Bulu babi adalah spesies penting dan merupakan salah satu spesies kunci dalam ekosistem terumbu karang dan lapisan rumput laut. Keberadaannya di perairan berperan sebagai penyeimbang ekosistem terumbu karang. Sayangnya, di beberapa tempat, kegiatan penangkapan bulu babi telah mengalami overfishing sehingga jumlahnya semakin berkurang di alam (Nane 2019b; Nane \& 
Paramata, 2020). Jika populasi landak laut meningkat, ini dapat berakibat pada hilangnya nyawa bagi larva muda atau karang. Sebaliknya, jika populasi menurun akan mengakibatkan karang akan ditumbuhi alga yang menyebabkan kematian pada karang dewasa dan tidak ada lokasi untuk larva karang. Dengan demikian keberadaan bulu babi sangat penting bagi terumbu karang dan rumput laut sebagai penyeimbang (Toha, 2006 dalam Suistiawan dan Rahman, 2019).

\section{Conclusion}

Indonesia sebagai negara kepulauan yang telah dikenal memiliki sumber daya alam yang sangat tinggi, kehidupan tumbuhan dan fauna. Pantai adalah daerah sekitar yang menjadi batas antara laut dan darat. Pantai ini memiliki beragam kehidupan laut, salah satunya yaitu bulu babi. Bulu babi tercakup dalam klasifikasi Echinodermata dan Echinodermata yang merupakan hewan laut yang memiliki struktur bundar dan memiliki duri pada kulitnya yang dapat dipindahkan, Di Indonesia, ada sekitar delapan puluh empat jenis bulu babi dari 31 famili dan empat puluh delapan genera, Echinodermata merupakan invertebrata laut yang dicirikan melalui kulit yang keras dan berduri. Echinodermata memiliki aktivitas yang akrab di setiap kedalaman lautan, dari daerah pasang surut hingga zona abyssal. Bulu babi ialah hewan laut yang sering ditemukan di ekosistem air laut dengan hamparan padang lamun. Peran bulu babi dari hasil penelitian tentang kemampuan untuk mengambil makanan bulu babi siang hari sementara pada waktu malam hari landak laut kurang energik dalam merumput, kenyataan yang relatif bertentangan dengan kebiasaan landak laut di konvensional yang menyamar hanya pada tahap tertentu dalam sehari. Dan Bulu babi juga ialah hewan laut yang sering ditemukan di ekosistem air laut dengan hamparan padang lamun. Hewanhewan ini membuat hubungan simbiosis khusus dengan ikan yang menggunakan ekosistem serta membantu ekosistem padang lamun.

\section{References}

Ahmed, Q., Ali, Q. M., Mubarak, S., \& Farooq, S. (2016). Studies on the seasonal abundance and diversity of Echinoderms (Asteroidea, Oophiuroidea, Echinoidea, and Holothuroidea) from coastal areas of Karachi (Northern Arabian Sea). Pakistan Journal of Marine Sciences, 25(1\&2), 101-117.

Aisyah, S., \& Romadhon, A. (2020). Hubungan Persen Penutupan Lamun Dengan Kepadatan Echinodermata Di Pulau Bawean Kabupaten Gresik Jawa Timur. Juvenil, 1(1), 132- 140. 
Ali, A. I., Suryanti, S., \& Sulardiono, B. (2017). Kelimpahan Dan Pola Sebaran Echino Dermata Di Pulau Karimunjawa Jepara.

Ariyanto, T. P. (2016). Keanekaragaman dan Kelimpahan Echinodermata di Pulau Barrang Lompo Kecamatan Ujung Tanah Kota Makassar (Doctoral dissertation, Universitas Islam Negeri Alauddin Makassar).

Arthaz, C. P. (2015). Hubungan Kelimpahan Bulu Babi (Sea Urchin) Dengan Bahan Organik Substrat Dasar Perairan Di Pantai Krakal, Yogyakarta. Management of Aquatic Resources Journal, 4(3), 148-155.

Ayuwati, R. N. Pola Distribusi Jenis Echinoidea Di Zona Intertidal Tanjung Bilik Taman Nasional Baluran.

Erlangga, Y., El Rahimi, S. A., \& Devira, C. N. (2018). Struktur Komunitas Echinodermata di Perairan Pantai Gapang, Desa Iboih, Kecamatan Sukakarya, Sabang. Jurnal Ilmiah Mahasiswa Kelautan Perikanan Unsyiah, 3(1).

Erlangga, Y., El Rahimi, S. A., \& Devira, C. N. (2018). Struktur Komunitas Echinodermata di Perairan Pantai Gapang, Desa Iboih, Kecamatan Sukakarya, Sabang. Jurnal Ilmiah Mahasiswa Kelautan Perikanan Unsyiah, 3(1).

Firmandana, T. C. (2014). Kelimpahan Bulu Babi (Sea Urchin) pada Ekosistem Karang dan Lamun di Perairan Pantai Sundak, Yogyakarta. Management of Aquatic Resources Journal, 3(4), 41- 50.

Irianto, A., Jahidin, J., \& Sudrajat, H. W. (2016). Kelimpahan Bulu Babi (Echinoidea) Di Intertidal Perairan Pulau Liwutongkidi Kecamatan Siompu Kabupaten Buton Selatan. Jurnal Ampibi (Almuni Pendidikan Biologi), 1(2).

Jalaluddin, J., \& Ardeslan, A. (2017). Identifikasi Dan Klasifikasi Phylum Echinodermata Di Perairan Laut Desa Sembilan Kecamatan Simeulue Barat Kabupaten Simeulue. Jurnal Biology Education, 6(2).

Juliawan, J., Dewiyanti, I., \& Nurfadillah, N. (2017). Kelimpahan dan Pola Sebaran Bulu Babi (Echinodea) di Perairan Pulau Klah Kota Sabang. Jurnal Ilmiah Mahasiswa Kelautan Perikanan Unsyiah, 2(4).

Kurniawan, M. R., Nasution, S., \& Yoswaty, D. Community Structure Of Echinoderms In Aquatic Park Of Pieh Island West Sumatra (Doctoral dissertation, Riau University).

Laut, S. (2019). Keanekaragaman Bulu Babi (Echinoidea) Pada Kawasan Lamun Di Perairan Desa Langara, Kecamatan Wawonii Barat Kabupaten Konawe Kepulauan.

Moningkey, R. D. (2011). Peran Ekologi Bulu Babi dalam Komunitas Rumput Laut di Perairan Pesisir Kema Kabupaten Minahasa Utara. Jurnal Perikanan dan Kelautan Tropis, 7(1), 1-5. 
Nane, L. (2019a). Efisiensi Mesin Teknologi Sapurata Dalam Mengoptimalisasi Produksi Inovasi Pangan Kukure Di Pulau Barrang Lompo, Makassar. https://doi.org/10.31230/osf.io/q8spg

Nane, L. (2019b). Impact of overfishing on density and test-diameter size of the sea urchin Tripneustes gratilla at Wakatobi Archipelago, south-eastern Sulawesi, Indonesia. BioRxiv, 727271. https://www.biorxiv.org/content/10.1101/727271v1

Nane, L. (2019c). Sea Urchin Sustainability Studies Based on Dimension Biology, Ecology and Technology at Around of Tolandono Island and Sawa Island at Wakatobi Conservation Area. https://doi.org/10.31230/osf.io/4whz6

Nane, L., \& Paramata, A. R. (2020). Impact of Overfishing on Density and Test-Diameter Size of the Sea Urchin Tripneustes gratilla at Wakatobi Archipelago, South-Eastern Sulawesi, Indonesia. ILMU KELAUTAN: Indonesian Journal of Marine Sciences, 1(1). https://ejournal.undip.ac.id/index.php/ijms/article/view/28074

Nane, L., Baruadi, A. S. R., \& Mardin, H. (2020). The density of the blue-black urchin Echinotrix diadema (Linnaeus, 1758) in TominiBay, Indonesia. Tomini Journal of Aquatic Science, 1(1), 16-21. https://doi.org/10.37905/tjas.v1i1.5939

Noviana, N. P. E., Julyantoro, P. G. S., \& Pebriani, D. A. A. (2019). Distribusi dan Kelimpahan Bulu Babi (Echinoidea) Di Perairan Pulau Pasir Putih, Desa Sumberkima, Buleleng, Bali. Current Trends in Aquatic Science, 2(1), 22-29.

Nugroho, P. E. R., Purnomo, P. W., \& Suryanti, S. (2018). Biodiversitas Echinodermata Berdasarkan Tipe Habitatnya Di Pantai Indrayanti, Gunungkidul, Yogyakarta (Biodiversity Echinoderms Based On Habitat Type In Indrayanti Beach, Gunung Kidul, Yogyakarta). Management of Aquatic Resources Journal, 6(4), 409-414.

Nurafni, N., Muhammad, S. H., \& Sibua, I. (2019). Keanekaragaman Echinodermata di Perairan Pulau Ngele Ngele Kecil, Kabupaten Pulau Morotai. Jurnal IImu Kelautan Kepulauan, 2(2).

Padang, A., Nurlina, N., Tuasikal, T., \& Subiyanto, R. (2019). Kandungan Gizi Bulu Babi (Echinoidea). Agrikan: Jurnal Agribisnis Perikanan, 12(2), 220-227.

Purnomoa, I. G. P. A., Dharma, I. S., \& Putraa, I. N. G. Struktur Komunitas dan Sebaran Bulu Babi (Echinoidea) di Kawasan Padang Lamun Pantai Serangan, Bali.

Purwandatama, R. W., \& Ain, C. (2013). Kelimpahan Bulu Babi (Sea Urchin) pada Karang Massive dan Branching di Daerah Rataan dan Tubir di Legon Boyo, Pulau Karimunjawa, Taman Nasional Karimunjawa. Management of Aquatic Resources Journal, 3(1), 17-26. 
Putri, A. E. M., Sunaryo, S., \& Endrawati, H. (2019). Perbandingan Jenis dan Jumlah Echinodermata Di Perairan Pantai Krakal Gunung Kidul Yogyakarta Dan Pantai Pailus Jepara, Jawa Tengah. Journal of Marine Research, 8(2), 127-140.

Rondonuwu, A. B., \& Watung, V. N. (2015). Distribusi dan Kelimpahan Pterapogon kauderni Koumans, 1933 (Apogonidae) di Selat Lembeh Bagian Timur, Kota Bitung. Jurnal IImiah Platax, 2(3), 121- 126.

Setyawan, B., Sulardiono, B., \& Purnomo, P. W. (2014). Kelimpahan Bulu Babi (Sea Urchin) pada Ekosistem Terumbu Karang dan Ekosistem Padang Lamun di Pulau Panjang, Jepara. Management of Aquatic Resources Journal, 3(2), 74-81.

Silvina, S. (2017). Keanekaragaman echinodermata di zona intertidal Gili Trawangan Kabupaten Lombok Utara (Doctoral dissertation, Universitas Islam Negeri Mataram).

Somma, A., Zahida, F., \& Yuda, P. (2018). Kelimpahan dan Pola Penyebaran Bulu Babi (Echinoidea) di Terumbu Karang Pantai Pasir Putih, Situbondo, Indonesia. Biota: Jurnal IImiah IImuIImu Hayati, 3(2), 111-115.

Sulistiawan, R., Solichin, A., \& Rahman, A. (2019). Hubungan Kerapatan Lamun Dengan Kelimpahan Bulu Babi (Echinoidea) Di Pantai Pancuran Taman Nasional Karimunjawa, Jepara The Correlation of Seagrass Density with Abundance of Sea Urchins (Echinoidea) in Pancuran Beach Karimunjawa National Park, Jepara. Management of Aquatic Resources Journal, 8(1), 28-36.

Syam, A. R., \& Andamari, R. (2017). Populasi dan tingkat pemanfaatan bulu babi (Echinoidea) di Padang Lamun Pulau Osi, Seram Barat, Maluku Tengah. Jurnal Penelitian Perikanan Indonesia, 8(4), 31-37.

Waters, I. K. B. (2010). Perkembangan Gonad Bulubabi, Tripneustes Gratilla, Yang Ditangkap Di Perairan Teluk Kupang.

Yudasmara, G. A. (2013). Keanekaragaman Dan Dominansi Komunitas Bulu Babi (Echinoidea) Di Perairan Pulau Menjangan Kawasan Taman Nasional Bali Barat. JST (Jurnal Sains dan Teknologi), 2(2). 